\title{
Chapter 11 \\ "Impossible" Activism and the Right \\ to Be Understood: The Emergent Refugee \\ Rights Movement in Finland
}

\author{
Camilla Haavisto
}

\subsection{Introduction}

The breaking down of the Finnish political consensus culture (Nieminen 2010), together with a hybridization of the communicative space (Chadwick 2013) and the electoral successes of The Finns Party since 2008, has created a new environment in Finland for debates on refugee-related matters. In these debates, anti-immigration arguments are presented not only by the candidates of The Finns Party, but a range of politicians from across the political spectrum (Horsti and Nikunen 2013). This applies to face-to-face debates, legacy media and social media alike. Particularly on social networking sites (SNS), the voices of "White, angry welfare protectionists" have grown loud. These voices are backed up by claims that are more moderate in tone, and together they both echo and construct collective imaginaries of welfare nostalgia and threat. In the threat imaginaries, Finland is envisioned as an innocent and rational State under siege from a chaotic, ethnically diverse and hostile world. (Pettersson 2017; Pyrhönen 2017; Schierup et al. 2018, and Hellström et al., Chap. 1 in this volume).

In this communication environment, there is little mediated space for asylum seekers and refugees to come to the forefront with their views and experiences of how the State respects their right to seek protection, evaluates security in their former homeland, and balances between dichotomies and conflicting principles such as safety vs. risk, human rights vs. control, threat/burden vs. asset.

One tactic for asylum seekers to increase their ability to be heard in public is to organize demonstrations in central urban spots or in connection with asylum

\footnotetext{
C. Haavisto $(\square)$

Swedish School of Social Science, University of Helsinki, Helsinki, Finland e-mail: camilla.haavisto@helsinki.fi 
centers. Accordingly, the Right to Live demonstration ${ }^{1}$ was initiated on 10 February 2017 in central Helsinki with the main purpose of creating awareness around refugee rights and deportation practices upheld by the State. This occurred in the aftermath of political protests led by asylum seekers in Berlin, Vienna, Cairo, New York and elsewhere in the world. As internationally, also in Helsinki, the form of the demonstration was a sit-in demonstration, or protest camp in Gavin Brown et al.'s (2018) and Anna Feigenbaum et al.'s (2014) conceptualization. The demonstration, which lasted over the winter, spring and summer, until 17 September, was debated on various online forums, often in relation to a migration-critical counter demonstration initiated on the same urban spot by demonstrators who held opposite socio cultural values and political agendas to the asylum seekers and their allies, namely migration criticism, welfare nostalgia and so-called Euroscepticism.

Examining how and by whom the Right to Live demonstration was discussed in public, I explore in this chapter how, if at all, spontaneously formed social engagement groups led by asylum seekers and Finnish allies manage to direct the public debate over refugee rights towards increased humanitarianism, justice in the asylum process and awareness of the security situation in regions of war and conflict. This is done in a theoretical framework built around the paradoxical relation between the "right to be understood" (Husband 1996) and "impossible activism" (Nyers 2003). While, according to Charles Husband (1996, 2009), marginalized collectives should ideally have "the right to be understood" as a so-called third generation human right, in practice, not all have the opportunity to become political subjects who can make claims on welfare services, security and protection. In the context of migrant protests, this argument appears to be particularly true, as shown in studies by Ilker Ataç (2016), Jouni Häkli et al. (2017), Sara de Jong and Ilker Ataç (2017), Peter Nyers (2003), Carolina Moulin and Peter Nyers (2007).

In contrast to many of the international sit in-demonstrations, such as the one organized outside the offices of the United Nations High Commissioner for Refugees (UNHCR) in Cairo in 2005 (Moulin and Nyers 2007), the Right to Live demonstration was a joint endeavor of migrant protesters from Iraq and Afghanistan and their Finnish allies. How, if at all, the multi-ethnic, multi-lingual, open and collaborative nature of the endeavor came to influence how claims of increased humanitarianism and refugee rights came to be circulated and heard in the communication environment, and how, if at all, they came to empower a public discourse of hope rather than nostalgia, is discussed further in this chapter.

\footnotetext{
${ }^{1}$ The Right to Live demonstration is not be confused with a US-based movement on reproductive rights with nearly the same name. The two initiatives are unrelated.
} 


\subsection{From Grateful Refugee to Political Subject}

To understand the significance of a sit-in demonstration led by migrant protesters and their allies in the context of Finland, one must relate the protest to certain fluctuations taking place in contemporary civil society with regard to anti-racist activism, refugee rights and anti-deportation movements. There are four phenomena that require a brief overview.

First, due to the center-right Government's (PM Juha Sipilä 2015-2019) tightened asylum policies, it seems that the significance of traditional top-down led NGOs is diminishing while the role of spontaneous network type of initiatives (Peli Poikki - Enough is Enough demonstration), and groups formed ad hoc in online environments is increasing (e.g., We see You and Refugee Hospitality Club Finland). This phenomenon may be influenced by the Finnish Government's funding cuts to so-called humanitarian NGOs (Yle 2015, July 9), but this is not the whole reason, since broader phenomena, such as the digitalization of our everyday lives and an increased tendency for citizens to "bypass" the state and to mistrust elites leading to new social movements (Offe 1984), also play a role.

Although not a new phenomenon, this is still a noteworthy trend, since Finland has traditionally been the "promised land" of NGOs, and as in the other Nordic countries, the state and civil society have been and are still closely related today (Haggrén et al. 2005; Luhtakallio 2012). Hence, in Alana Lentin's (2004) theorizing of anti-racist activism as existing along a continuum of proximity-to-distance from the public political culture of the nation-state (Rawls 1993 [2005]), most Finnish civic refugee rights and anti-racist movements have traditionally been in line with the public political culture.

Second, in Finland, although the founding of Antifa Finland in 1992 marked the beginning of a more spontaneous and confrontational agency in the field of refugee rights and antiracism, street politics is a marginal phenomenon in comparison to Sweden or France, for example (see: Pries and Brink Pinto 2013, and Jämte 2013 for Swedish NGOs and movements against racism; Luhtakallio 2012 for Finnish civil society at large; Seikkula 2019, and Alemanji and Mafi 2018 for mainstream types of anti-racist agency in Finnish civil society). However, the organizing of antimigrant collectives to patrol the streets in the midst of the intensified entry of asylum seekers to Finland in 2015-2016, as well as a few deportation cases that evoked great public furore, have lately given rise to an increased number of street-level engagements for increased refugee rights both in the capital area and elsewhere.

Third, today, when a large part of the communication practices of refugee rights groups and spontaneously organized collectives take place on social networking sites, new challenges are emerging. These sites, platforms and forums are crucial for the organizing of campaigns and events, and at the same time, because much of this activity takes place on social networking sites, they are vulnerable to fake profiles, trolling and hate (see: Gustafsson 2019, May 15 for a contemporary court case against 24 people convicted for defamation). 
Four, it is noteworthy that in Finnish street politics for migrant rights, there are few participants from migrant groups that arrived in the country decades ago, from e.g. Chile or Somalia, which contributes to a White ambiance at many demonstrations. The modest participation of migrants and refugees in larger protest movements in Finland may relate to a collective feeling of gratitude for the right to enter one of the most politically stable countries in the world, for tax funded allowances, for services such as refuge, food, medical care, and language training (Yijälä and Nyman 2017, p. 83; Kokkonen 2010). These feelings of gratitude may be mixed with guilt and also frustration at having to feel and show gratitude towards something as abstract as a State. Perhaps it is the "obligation of gratitude" (Ong et al. 2015), as experienced by self and others, rather than gratitude in itself that affects the willingness of migrants living in Finland to enroll in great numbers in protest movements.

However, recently, Finnish activists have become more aware of their lack of legitimacy to speak up about certain refugee related matters, and as is argued in this chapter, there is a new type of more prominent migrant figure that emerges in and through self-expression ${ }^{2}-$ one who demands visibility, voice, rights, and fairness when it comes to how the State, anti-migration collectives and their allies relate to matters of representation, ethnicity, and race.

\subsection{Towards Becoming Understood}

To envision the refugee in this strong position, as a political subject, someone who has a legitimate voice that is heard by elites and others, is a controversial suggestion. Peter Nyers (2003) has introduced the concept of "impossible activism" when referring to the political self-organizing of asylum seekers, refugees, non-status residents. He means that such activism tends to reveal problems as well as new ways of thinking and acting politically. Questions rising are: who is to be protected; who will do the protecting; who represents those in need of protection; can the endangered $^{3}$ speak for themselves; what are the possibilities and constraints that (dis) allow political activism by non- or quasi-citizens? (Nyers 2003, p. 1071) He states, "Not surprisingly, representatives of the sovereign order display a striking anxiety whenever the abject foreigner takes on the status of a political activist engaged

\footnotetext{
${ }^{2}$ Asylum seekers in Finland have been engaged in direct political advocacy also before 2017, although these actions have received only little attention from the legacy media (Horsti and Pellander 2018).

${ }^{3}$ There are plenty of notions used for queries about if, when and how endangered, vulnerable, minoritized, or racialized individuals and collectives get to speak up about issues concerning them. Spivak (1996 [1985], p. 214) talks about the subaltern, Nyers (2003, p. 1073) about the abject foreigner, Chouliaraki (2013) and Eide (2017) about vulnerable others. As I see it, vulnerability is a "productive position, condition, or state that does something", something more than a "lamentable condition from which subjects should be defended, rescued or liberated" (The Engaging Vulnerability-project 2016). See also Dancus, Hyvönen \& Karlsson (2020).
} 
in acts of self-determination (e.g., stopping his/her deportation)." (Nyers 2003, p. 1078).

This anxiety, I suggest, carries certain consequences for the preparedness and willingness of political elites, journalists, and other key figures in the public debate to understand the process of asylum from the point of view of the protesting asylum seeker - sometimes perhaps more a subconscious than conscious position, other times as a means of doing nationalistic politics.

A theoretical notion that challenges the nationalistic and nostalgic collective imaginaries of an ethno-nationalistically united "we", is Charles Husband's (1996, 2009) concept of the "right to be understood". According to Husband, following the principle of the right to be understood means to actively seek to comprehend minorities. For Husband (2009, p. 141), the right to be understood is a collective right within what can be envisioned as the "third generation human rights", i.e., collective rights that go beyond the mere civil and social. In my reading of Husband, this "right" is intended to balance the share of rights and obligations in the communicative space so that the right to free speech would not rule out moral obligations, such as a willingness to listen to social groups in vulnerable positions in society. Following Iris Marion Young, Husband (1998, pp. 139-140) calls for an active state that guarantees equity of participation through the creation of state institutions capable of advancing mechanisms and processes to aid understanding across boundaries such as ethnicity, culture, and religion. At the core of the theoretical idea lies the ideal of the state being able to nurture solidarity towards vulnerable social groups. This, according to Husband (1996, p. 4), requires a moral sensibility which underpins a reflexive self-consciousness in regard to in-group values, that is, who "we" are and what is important to "us", and a recognition of solidarity with minorities.

Not all "minorities" are citizens, which brings us back to Nyers (2003; Moulin and Nyers 2007) and the question on whether asylum seekers, as abject ${ }^{4}$ foreigners with a variety of legal statuses, can be expected to have collective rights in the field of communication, particularly when it comes to self-expression and a respectful and imaginative recognition of their political claims? And if so, can the State and its institutions be expected to be those "who understand" them and engage with their claims? My answer is yes. According to article 14 of the Universal Declaration of Human Rights (1948), everybody is guaranteed the right to seek and enjoy asylum in other countries. Subsequent regional human rights instruments have elaborated on this right, which in practice means that asylum seekers have the right to appeal decisions by migration authorities to a court. Legal and political decision-making cannot be fully detached from the mediated discourses as media, through agenda setting (McCombs 2005) and mediatization (Hepp et al. 2015), influence the ideological context in which the decisions are made, and also are influenced by these ideological contexts. Accordingly, as I see it, asylum seekers also have the right to self-expression in the public debate in which elites and citizens share information,

\footnotetext{
${ }^{4}$ The abject is someone who is cast-out, discarded, and rejected (Nyers 2003, p. 1073).
} 
debate over moral and ethical questions and - in an ideal democracy - also scrutinize policies and decisions made by national and supranational institutions.

\subsection{Material and Method}

This chapter creates a synthesis of three different sets of empirical material ${ }^{5}$ : interviews with protesting asylum seekers and their allies, analysis of legacy media, and big data analytics from Facebook. The first set of data consists of interviews with 19 protesting asylum seekers and their allies; the second set consists of 57 news articles in legacy media covering 13 news articles on the Yle web-site (the national broadcasting company), 16 in Helsingin Sanomat (the main Finnish-language national paper), 6 in Hufvudstadsbladet (the main Swedish-language national paper), 10 in Iltalehti (evening paper), and 12 in Turun Sanomat (regional paper). The third set consists of 3643 postings and comments published in Facebook groups between February 2017 and June 2017.

The in-depth interviews with activists, both asylum seekers and their Finnish allies, and the legacy media content have been analyzed using close reading (Lentricchia and DuBois 2003) in Atlas.ti. The big data material was collected from the Facebook API by means of a custom-built tool (https://github.com/HIIT/hybrasomeloader, see Nelimarkka et al. 2018) and the material has been analyzed using close reading and computational methods, such as link analysis. The material was collected before Facebook implemented new regulations, forbidding data from public groups from being collected without the consent of the group administrator. Despite this, with regard to research ethics, I do not refer to individuals and I do not use direct quotes from the big data.

The four pro-migration groups analyzed on Facebook are: "We see You", a community with 8800 followers, "Stop Deportations", a community organization with over 14,000 followers, Rasmus-valtakunnallinen rasismin ja muukalaisvastaisuuden verkosto (Rasmus - the national network against racism and xenophobia), a group with over 16,000 members, and "Refugee Hospitality Club", a group with 14,000 members. The four anti-migration sites on Facebook examined are Minun Suomeni on sinivalkonen (My Finland is blue and white), a group with over 4400 members, Suomi Ensin-foorumi (Finland First Forum), a public group with over 4400 members, Rajat Kiinni-kansanliike (The civic movement Close the Borders), a public group with more than 9900 members and Maahanmuuttokriittiset (The migration critics), a group with more than 5100 members as of 2018.

\footnotetext{
${ }^{5}$ The empirical material was obtained by the Academy of Finland project Anti-racism under pressure: Social movements, NGOs and the mediated claims-making (2013-2016/2018) in collaboration with the Academy of Finland consortia Racisms and public communications in the hybrid media environment (HYBRA) (2016-2019). The help of my research assistants, Juho Pääkkönen and Erna Bodström, has been crucial in the collection and organizing of the empirical material.
} 
I roughly categorize these groups into pro-migration and anti-migration groups in order to grasp general trends in the debate but it must be kept in mind that the groups within the two categories are not identical in character. For example, Rasmus contains more comments on a much broader register for and against migration than the three other groups in the pro-migration category. Maahanmuuttokriittiset (The migration critics), again, contains more respectful and dialogical commenting than the three other groups in the anti-migration category.

\subsection{The Reasons to Protest and the Formation of the Camp}

After the arrival of an all-time record of 20,485 Iraqi and 5214 Afghan asylum seek-

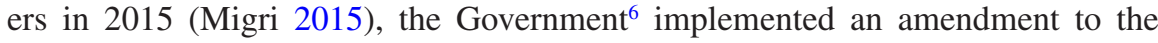
Aliens Act (HE 2/2016 vp), stating that after 16 May 2016, if a person does not meet the requirements for asylum or subsidiary protection, Finland can no longer grant the person humanitarian protection. ${ }^{7}$

At the same time, Finnish immigration officials revised their security assessments for Afghanistan, Iraq and Somalia. They stated that it was safe for nationals to return to their home countries, making it more difficult for asylum seekers from these countries to receive residence permits in Finland (Migri 2016). During spring 2017, there was also well-grounded information about at least one case in which a man was deported against his will, despite not having received a final decision regarding his asylum application (Svenska Yle 2017, February 20). In addition, during the same spring, inaccurate decision making in the asylum administration also began to be documented by persons other than human rights activists. According to the Finnish Migration Service - a government agency under the Ministry of the Interior $-4 \%$ of all negative decisions come back to the Migration Service from the Administrative Court because of an erroneous handling of the case by the Migration Service, whereas in 2015, the proportion was only $0.2 \%$ (Rämö 2017).

To protest against these alleged wrong-doings by the Finnish state, on February 12th, 2017, a few migrants with connections to the refugee rights activist network, the Free Movement Network (founded in 2006), formed an ad hoc sit-in demonstration that soon started to attract more participants.

\footnotetext{
${ }^{6}$ In May 2015, The Finns Party joined Finland's coalition government for the first time after finishing second in the national elections, ushering a move away from pro-immigration and pro-EU policy. During spring 2017, the party split into two groups, The Finns Party, led by Jussi Halla-aho, and a group initially called the "New Alternative" and later the "Blue Reform". The latter continued as part of PM Juha Sipilä's center-right government until the parliamentary elections in 2019. ${ }^{7}$ The amendment meets the minimum requirements set by the Refugee Convention (1951) but still tightens the rules around asylum as before May 2016, it was possible according to $\S 88$ in the Aliens Act (HE 2/2016 vp) to grant protection on humanitarian grounds to a person even if he/she did not meet the requirements set out by $\S 87$ and $\S 88$ in the Aliens Act.
} 
The sit-in demonstration was originally planned to be a brief publicity-attracting event, but it was prolonged day by day without a clear decision or plan for how to proceed. Tents and sleeping bags were brought in to the initial central spot of the demo by Finnish supporters who had heard about the demonstration in social media or through their affiliation with the Free Movement Network.

Many informants, migrants and allies alike, speak of the formation of the sit-in demonstration as "chaotic", and a continuous and tiresome struggle with city authorities and political opponents (the migrant-critical counter-demonstration) for their pure right to exist. Despite this "survival mode" and harsh winter climate, political claims became refined as a collaboration between the three subgroups (Iraqis, Afghans, and Finns) and distributed online on various forums. Leaflets were printed, meetings with decision-makers and supporters were organized, press releases sent out, and the tent area was kept clean in order to avoid dirtiness being used as justification for the Police to evict the area - the last, a demanding task in a spot where no infrastructure such as heat, water, toiletry or garbage services are provided for. Taking care of these tasks was possible as the collective transformed from a loose network of strangers into a close circle of friends. Both migrant protesters and their allies soon started referring to their collective as the "Demo family".

\subsubsection{Who Represents Whom?}

An important feature of the "Demo family" was a continuous discussion over representation. Some of the allies had expertise in public relations and, also because of their much-needed skills in Finnish (and Swedish, in order to serve the Swedishlanguage media in Finland), PR tasks were mainly planned by the allies. However, in situations where journalists or politicians visited the protest site, the allies systematically guided the visitors towards the migrant protestors. For the collective, it was important that the sit-in demonstration in public was presented as a migrant endeavor. For this reason, the initial unofficial connection to the Free Movement Network was also often silenced and research interview questions that related to leadership or the choice of spokespersons were often answered cryptically. The Finnish allies were, for example, told to chair weekly meetings because the Finnish way of having meetings was appreciated by all, not because they would be in charge.

Most of the internal conflicts, such as difficult personal relations, or worsened group relations between the Arabic speakers and the Dari speakers, were also intentionally overlooked by the migrants and the Finnish allies alike in order to keep the ideal of a non-hierarchical and democratic organization alive (see: Laaksonen et al. forthcoming for more on how authority within the organization was formed). In practice, however, there were people within the collective who played the roles of leaders, spokespersons, and representatives for others. Various power positions were constructed via everyday activities (for example, carrying water to the camp was a low-status task, cooking high-status, etc.), but power positions were also constructed through social media actions that could both exclude and include. 
It was much easier for the migrant protestors to talk about their role as representatives for asylum seekers outside the demonstration site than about issues relating to internal leadership and group relations. Many of the migrant protestors saw themselves as representatives of families and children residing far from the capital area, and of people whose skills in English were insufficient to follow currents and undercurrents in policy-making. Some of the migrant protestors had launched and now administrated active social media networks to better reach these groups and individuals. Information on upcoming deportations or bad conditions at certain reception centers could be shared via these sites and other networks managed by the migrant protestors. The administrators of these sites claim that they have become known persons within their communities - persons who "bring hope" to desperate individuals and families who deal with negative asylum decisions and struggle with the authorities. Hence, the migrant protestors administrating popular demo-related Facebook groups in Arabic and Dari seem to have become important nodes for transmitting various kinds of grassroots information from reception centers in the provinces to Finnish pro-migration activists, and vice versa.

\subsubsection{Law, Order, and Security in Legacy Media}

Another factor contributing to the cumulative burden of the sit-in demonstration was the constant feeling of claims being misinterpreted or neglected by legacy media. In the established news media, the Right to Live demonstration was discussed mostly in relation to the anti-migration counter-demonstration. Together the two sit-in demonstrations were framed as a problem - a problem of law and order in the city center, and a potential provocation to more serious security-related threats. What kinds of threats, from whom, directed where, and how the Police knew about these threats was left unclear, despite the fact that representatives for the Police had earlier stated that "everything has worked out well with the Right to Live demonstration" (Finnish News Agency STT 2018, 26 June). The claims put forward by the migrant protestors of brutal and systematic violence in regions to which former asylum seekers were deported from Finland, and claims of severe problems within the migration administration, were left aside by journalists in their stories on the demonstration. Instead, the responsibility to explain in legacy media what really happened on site was handed to the Police. In fact, the situation was persistently framed by journalists as a matter of law and order, leaving no room to clarify why the asylum seekers were protesting. In the interviews, the migrant protestors expressed sentiments of having been betrayed by the journalists. Migrant protestors claimed in the research interviews that they got to argue their case freely when interviewed by journalists, but, once the story came out, only a brief "nonsense quote" had been published instead of all the political claims that they had put forward.

The framing of the issue as a case of law, order and security on the expense of human rights perspectives, echoes prior studies on news on migration (Benson 
2013). However, what distinguishes the reporting on the Right to Live-demonstration from migration news in general is the exceptionally strong polarization of migrants and so-called immigrant critics, and the focus on rather mundane concerns, such as littering in urban space, rather than on, for example, controlling migration flows and demographic anxieties (see Hellström et al., Chap. 1 in this volume). Concerning polarization, what we see here is that the emerging migrants' rights movement led by migrants and their allies in Finland was so persistently presented through a polarized angle that it seems difficult to break even in situations where polarity cannot be seen on the field. For example, in reporting on a regional support demonstration in the city of Kotka where anti-migrant activists were not present, their very absence became a point of emphasis. In other words, instead of being allowed to form claims relating to the actual pro-asylum agendas, organizers were quoted on how relieved they were that the atmosphere was peaceful and no counter-demonstrators were present (Pisto 2017, March 11).

\subsubsection{Human Rights and Welfare in Social Media}

Issues of law, order and security are emphasized on Facebook as well, but the perspective taken is very different depending on the site concerned. On the promigration sites, the broader circle of sympathizers with the migrants' demonstration who mainly identify as "native" Finns, center the discussion on the disturbance and harassment from the immigrant critical counter-demonstration. Rumors about NeoNazi "raids" on the site of the demonstration were discussed on these pro-migration sites and security measures contemplated (for example, a child-friendly pro-migrant event was planned with the aid of staff from the neighboring ice-skating rink but can celled last-minute for alleged security reasons). The Police's lack of interest in coming to the site when asylum seekers made telephone calls in order to get protection from the immigrant critics were also discussed by the broader circle of sympathizers.

Despite the discussion about harassment, trouble and security risks, the predominant frame for discussion in the pro-migration groups was that of human rights. This is particularly true in posts by supporters of the demonstration who identify as "native" Finns. Particularly at the beginning of the demonstration, when migrant children and families spent time at the tent, this frame dominated the discussion. This frame was constructed by strong criticism towards the Finnish Migration Service, political elites, and the center-right Government of PM Juha Sipilä.

In this setting, the role of debaters who self-identify as asylum seeker is threefold. First, the migrant protestors and asylum seekers are "fact providers" who post visual and textual material from foreign sites in order to show proof of the current safety situation in Afghanistan and Iraq. The content circulated is often in Arabic and contains pictures showing brutality. Although this kind of content does not 
necessarily translate well into culturally Finnish mindsets, the claims formed in relation to the material tend to be powerful (e.g., "Baghdad is not safe. Don't send me back there!"). Second, the migrant debaters are the "experience experts" who in affect-laden posts and by using online translation tools or rudimentary Finnish, express a variety of feelings, ranging from wary hope to extreme frustration for their difficult and uncertain situation. And third, they are "help-seekers" who through these forums appeal for help for various personal problems, mostly relating to legal issues and/or health. Call-outs for help were also sent out by "native" supporters who volunteered with document translation, housing, employment, or visits to authorities. These appeals from both migrants and volunteers were on most occasions met with expressions of solidarity, and many times also with advice leading to a solution. Hence, on a micro-level, these groups function as "networked communities of support" that challenge the so-called "crisis of solidarity" (see Hellström et al., Chap. 1 in this volume).

On the contrary, on the so-called anti-migration sites, the tone of voice was hateful and one can barely speak of actual debate on the issue of deportation; rather there was a collective bashing of asylum seekers, migrants, their supporters, authorities, and the legacy media. The established news media were alleged to be in conspiracy with other powerful parties in order to hide the "real" problems and consequences of migration in general and Islam in particular (see: Pyrhönen 2017).

In these outbursts, commentators often brought up welfare issues. The underlying logic in these comments was that Finns are hardworking taxpayers who have to fund the slackness of migrants and to pay for them to be deported from "their holidays". The accusations were harsh, sometimes containing death threats or referring to a need for a "mass cleansing". What is interesting is that welfare nostalgia here functioned as some sort of justification for threats and ill wishes. The logic beneath this followed a pattern of "them" being here to use "our" welfare services and "our" tax money, which "they", according to the so-called migration critics, had no right to (see: Horsti and Nikunen 2013; Pettersson 2017; Pyrhönen 2017, for similar conclusions on social media discourses on migration politics).

What makes the welfare discourse particularly interesting in this case is that it was used both by parties supporting the anti-deportation movement and those opposing it, but for opposite goals. In the pro-migration sites, reference was made to the rapidly declining nativity in Finland and the potential of asylum seekers, as future taxpayers, to contribute to maintaining the Finnish welfare system. As typical in social media bubbles, a link analysis shows that these two understandings rarely met. This non-dialogical communicative agency around deportation also contained features of strong simplification as there were few attempts/opportunities to give the key notions, such as "welfare" or "human rights" a precise, deeper and contextbound meaning. The lack of precision and contextualization of these three key notions in popular debate risks watering down claims for and against deportation, and may obstruct the refugees' opportunities to be understood. 


\subsection{Strategies and Obstacles for Being Understood}

In the context of the theme of this volume, this chapter has examined some of the difficulties that contemporary humanitarian engagements in civil society face in a socio-cultural and economic climate where security, cultural protectionism, and neoliberal governability direct the media debate away from hopeful visions of humanitarianism, unity and global solidarity. Standing at the nexus of the right to be understood (Husband 2009) and the "impossibility" of political protest led by noncitizens (Nyers 2003), the aim of this chapter has been to provide a better understanding of whether asylum seekers involved in political protest manage to influence public debates on the core socio-cultural values in society, and if so, to examine the ways in which this influence works and the forms that it takes.

Drawing on a cross-reading of the three data sets (interviews with migrant protestors and their allies, legacy media content, and analyses of eight Facebookgroups), I have shown how issues of representation are difficult to overcome even when collectives explicitly strive to create a movement without hierarchies; how the legacy media frames complex issues on State responsibility, human rights principles, and the nature of democracy in terms of law and order in urban space; and how arguments on asylum and migration put forward by political opposites do not meet in social media.

The issue of representability, which in relation to the communication environment is illuminated by the stepping aside of the Finnish allies in public in favor of the asylum seekers and the sweeping under the carpet of disagreements, even ruptured relations, between ethnic groups, to me resembles more a strategy for being understood than an organizational problem. It seems that the collective, knowingly or semi-knowingly, essentialized themselves into a community of "asylum seekers", instead of e.g., Afghans and Iraqis and Finns - hence engaging in a sort of “strategic essentialism", in Gayatri Spivak's terms (1996 [1985]).

What this means on a general level is that the protestors seem to have provisionally accepted a common identity category in order to pursue a chosen political goal. Elisabeth Eide (2017) and others, even Spivak herself, dispute the notion of strategic essentialism and the ways in which the notion has been used. Perhaps, one could, as Eide $(2017,76)$ proposes between the lines, talk about a "standardizing of their public image" instead. By putting forward a "standardized public image", the group identity of the protestors was simplified and collectivized in order to achieve certain objectives, in this case for their claims on faults and injustices in the asylum system not only to be voiced in public but also listened to, understood and applied in both policy and administrative practice.

Unfortunately, as I have argued, the journalistic framing of the demonstration as an issue predominantly threatening urban order and the security of Finns, and the lack of dialogue, precision and respect for the "vulnerable other" in online milieus are hindering the migrants' efforts to be understood.

One can interpret the media focus on law and order in urban space as symbolic of how the State regains manageability over migration. Where manageability of 
migration is a lost game, perhaps primarily in the minds of welfare nostalgics, and in media discourses with an overblown crisis rhetoric, here, at a safe spot, not along State borders but in the middle of the city, around a few tents and portable toilets, manageability is symbolically regained.

Nyers (2003, p. 1090) has said, "[t]o be a refugee, to be political-is considerably difficult, if not impossible since radical takings of foreigners are always at risk of being deflected and absorbed by the non-democratic re-takings of sovereign power for the purposes of national and international (re)foundings." While the Right to Live-demonstration received recognition by Ministers who visited the camp and elite politicians who publicly supported their claims, the migrant protestors were unsuccessful in defining the conditions of this recognition, at least during and immediately after the protest.

By no means does the biased legacy media representation mean that the endeavors of the collective have been wasted. The protestors have created spaces where information exchange can occur in online media run by supporters of their cause. Through these multi-ethnic networks, activists, allies and supporters of the cause can seek evidence, map authority wrongdoings, and learn from one another (see: Jørgensen and Olsen, Chap. 10 in this volume). By doing so, they create a pool of invaluable, accumulated and grounded knowledge that draws on experience and expertise in Finnish laws and administration culture, but also on the transnational competencies so necessary to make sense of such complex phenomena as international migration movements and policies. These networks may have the potential to change policy and facilitate not only migrant voices but also majority and elite understandings of the asylum process and the security situation in the Greater Middle-East. So far, however, this is only an endeavor in the making.

\section{References}

Alemanji, A. A., \& Mafi, B. (2018). Anti-racism education in Finland: A study of an anti-racism workshop. Scandinavian Journal of Educational Research, 62(2), 186-199.

Ataç, I. (2016). "Refugee Protest Camp Vienna": Making citizens through locations of the protest movement. Citizenship Studies, 20(5), 629-646.

Benson, R. (2013). Shaping immigration news: A French-American Comparison. New York: Cambridge University Press.

Brown, G., Feigenbaum, A., Frencer, F., \& McCurdy, P. (2018). Introduction: Past tents, present tents: On the importance of studying protest camps. In G. Brown et al. (Eds.), Protest camps in international context: Spaces, infrastructures and media of resistance (pp. 1-22). Bristol: Policy Press.

Chadwick, A. (2013). The hybrid media system: Politics and power. Oxford: Oxford University Press.

Chouliaraki, L. (2013). Mediating vulnerability: Cosmopolitanism and the public sphere. Media, Culture and Society, 35(1), 105-112.

Dancus, A. M., Hyvönen, M., \& Karlsson, M. (2020). Vulnerability in Scandinavian art and culture. London and New York: Palgrave Macmillan.

de Jong, S., \& Ataç, I. (2017). Demand and deliver: Refugee support organisations in Austria. Social Inclusion, 5(3), 28-37. 
Eide, E. (2017). Strategic essentialism and ethnification: hand in glove? Nordicom Review, $31(2), 63-78$.

Engaging Vulnerability. (2016). Engaging vulnerability. Resourse document. University of Uppsala. http://www.engagingvulnerability.se/about-ev/about-engaging-vulnerability/. Accessed 15 Aug 2019.

Feigenbaum, A., Frenzel, F., \& McCurdy, P. (2014). Protest camps. London: ZedBooks.

Finnish News Agency STT. (2018, June 26). Poliisi lopettaa Suomi ensin-mielenosoituksen Helsingissä. Aamulehti. https://www.aamulehti.fi/kotimaa/poliisi-lopettaa-suomi-ensin-mielenosoituksen-helsingissa-200229304. Accessed 13 Oct 2018.

Gustafsson, M. (2019, May 15), Marjaana Toiviaista kutsuttiin verkossa saatanan kätyriksi ja mielisairaaksi. Helsingin Sanomat. https://www.hs.fi/kotimaa/art-2000006106058.html. Accessed 15 Aug 2019.

Haggrén, H., Hemstad, R., \& Marjanen, J. (Eds.). (2005). Civilsamhällets Norden: Papers presenterade på ett seminarium om nordiskt samarbete i januari 2004. Helsinki: CENS, University of Helsinki.

Häkli, J., Pascucci, E., \& Kallio, K. P. (2017). Becoming refugee in Cairo: The political in performativity. International Political Sociology, 11(2), 185-202.

HE 2/2016 vp, Hallituksen esitys eduskunnalle laiksi ulkomaalaislain muuttamisesta. https://valtioneuvosto.fi/paatokset/paatos?decisionId=0900908f805f2bd1. Accessed 15 Aug 2019.

Hepp, A., Hjarvard, S., \& Lundby, K. (2015). Mediatization: Theorizing the interplay between media, culture and society. Media, Culture and Society, 37(2), 314-324.

Horsti, K., \& Nikunen, K. (2013). Ethics of hospitality in changing journalism: The response to the rise of the anti-immigrant movement in Finnish media publicity. European Journal of Cultural Studies, 16(4), 489-504.

Horsti, K., \& Pellander, S. (2018). Visibility in mediated border scapes: The hunger strike of asylum seekers as an embodiment of border violence. Political Geography, 66, 161-170.

Husband, C. (1996). The right to be understood: Conceiving the multi-ethnic public sphere. Innovations, 9(2), 205-215.

Husband, C. (1998). Differentiated citizenship and the multi-ethnic public sphere. Journal of International Communication, 5(1-2), 134-148.

Husband, C. (2009). Between listening and understanding. Continuиm, 23(4), 441-443.

Jämte, J. (2013). Antirasismens många ansikten. Umeå: Statsvetenskapliga inst. Umeå universitet.

Kokkonen, L. (2010). Pakolaisten vuorovaikutussuhteet: Keski-Suomeen muuttaneiden pakolaisten kokemuksia vuorovaikutussuhteistaan ja kiinnittymisestään uuteen sosiaaliseen ympäristöön. Jyväskylä: University of Jyväskylä.

Laaksonen, S.M., Bodström, E., \& Haavisto, C. (forthcoming, accepted for publication). Finding the voice of a protest: Negotiating authority among the multiplicity of voices in a prorefugee demonstration. In C. Benoit-Barné \& T. Martine (Eds.), Speaking with one voice: New perspectives on organizing. Routledge Studies in Communication, Organization, and Organizing. Basingstoke: Routledge.

Lentin, A. (2004). Racism and anti-racism in Europe. London: Pluto.

Lentricchia, F., \& DuBois, A. (2003). Close reading: The reader. Durham/London: Duke University press.

Luhtakallio, E. (2012). Practicing democracy. London: Palgrave Macmillan.

McCombs, M. (2005). A look at agenda-setting: Past, present and future. Journalism Studies, 6(4), 543-557.

Migri. (2015). Maahanmuuttoviraston myöntämät ensimmäiset oleskeluluvat ja Suomen kansalaisuuden saaneet 2015. Document resource. https://migri.fi/documents/10197/5798793/64996_ Tilastograafit_2015_valmis.pdf. Accessed 15 Aug 2019.

Migri. (2016). Humanitarian protection no longer granted; new guidelines issued for Afghanistan, Iraq and Somalia. Press release. https://migri.fi/article/-/asset_publisher/humanitaaristasuojelua-ei-myonneta-enaa-uudet-maalinjaukset-afganistanista-irakista-ja-somaliasta. Accessed 15 Aug 2019. 
Moulin, C., \& Nyers, P. (2007). "We live in a country of UNHCR"-Refugee protests and global political society. International Political Sociology, 1(4), 356-372.

Nelimarkka, M., Laaksonen, S.M., \& Semaan, B. (2018). Social media is polarized, social media is polarized. Proceedings of the 2018 on designing interactive systems conference 2018-DIS '18. https://doi.org/10.1145/3196709.3196764.

Nieminen, H. (2010). The unravelling Finnish media policy consensus? In D. Levy \& R. Nielsen (Eds.), Changing business of journalism and its implications for democracy (pp. 55-68). Oxford: The Reuters Institute for the Study of Journalism, University of Oxford.

Nyers, P. (2003). Abject cosmopolitanism: The politics of protection in the anti-deportation movement. Third World Quarterly, 24(6), 1069-1093.

Offe, C. (1984). Contradictions of the welfare state. London: Hutchinson.

Ong, J., Flores, J., \& Combinido, P. (2015). Obliged to be Grateful: How local communities experienced humanitarian actors in the Haiyan response. Working paper, Plan International, UK. https://www.alnap.org/system/files/content/resource/files/main/obliged-to-be-gratefulreport.pdf. Accessed 15 Aug 2019.

Pettersson, K. (2017). Save the nation! A social psychological study of political blogs as a medium for nationalist communication and persuasion. Publications of the Faculty of Social Sciences, 51. Helsinki: University of Helsinki.

Pisto, V. (2017, March 11). Kouvolassa turvapaikanhakijoita tukeva mielenosoitus keräsi myös vastustajia - silti tapahtumat etenivät rauhallisesti. Yle Uutiset. https://yle.fi/uutiset/3-9504851. Accessed 15 Aug 2019.

Pries, J., \& Brink Pinto, A. (2013). 30 November: Kampen om Lund 1985-2008. Lund: Pluribus. http://lup.lub.lu.se/search/ws/files/5880285/4631516.pdf. Accessed 15 Aug 2019.

Pyrhönen, N. (2017). The true colors of Finnish welfare nationalism. Helsinki: University of Helsinki. SSKH Skrifter 38.

Rämö, A. (2017, July 27). Hallinto-oikeus jyrää yhä useamman Migrin ratkaisun. Suomen Kuvalehti. https://suomenkuvalehti.fi/jutut/kotimaa/hallinto-oikeus-jyraa-yha-useammanmigrin-ratkaisun-se-ei-tarkoita-etta-paatoksessa-olisi-mitaan-vikaa/?shared=979108677f5dcb-999. Accessed 15 Aug 2019.

Rawls, J. (1993 [2005]). Political liberalism. New York: Columbia University Press.

Refugee Convention. (1951). Convention relating to the status of refugees art. 1(A)(2), July 28, 1951. Resource document. https://www.unhcr.org/3b66c2aa10. Accessed 15 Aug 2019.

Schierup, C. U., Ålund, A., \& Neergaard, A. (2018). "Race" and the upsurge of antagonistic popular movements in Sweden. Ethnic and Racial Studies, 41(10), 1837-1854.

Seikkula, M. (2019). Adapting to post-racialism? Definitions of racism in non-governmental organization advocacy that mainstreams anti-racism. European Journal of Cultural Studies, 22(1), 95-109.

Spivak, G. C. (1996 [1985]). Subaltern studies. Deconstructing historiography. In D. Landry \& G. MacLean (Eds.), The Spivak reader (pp. 203-336). London: Routledge.

Svenska Yle. (2017, February 20). Refugee assistance NGO chief concerned about Finland's deportations. https://yle.fi/uutiset/osasto/news/refugee_assistance_ngo_chief_concerned_ about_finlands_deportations/9470370. Accessed 15 Aug 2019.

Universal Declaration of Human Rights. (1948). Resource document. http://www.un.org/en/universal-declaration-human-rights/index.html. Accessed 15 Aug 2019.

Yijälä, A., \& Nyman, M. (2017). Living in limbo: Qualitative case study of skilled Iraqi asylum seekers in Finland. City of Helsinki, Urban Facts 2017:1. https://www.hel.fi/hel2/Tietokeskus/ julkaisut/pdf/17_01_27_Tutkimuksia_1_Yijala_Nyman.pdf. Accessed 19 July 2019.

Yle. (2015, July 9). Development NGOs: Finland's disbursement cuts affect half a million peple. Online news article. https://yle.fi/uutiset/osasto/news/development_ngos_finlands_disbursement_cuts_affect_half_a_million_people/8142271. Accessed 15 Aug 2019. 
Open Access This chapter is licensed under the terms of the Creative Commons Attribution 4.0 International License (http://creativecommons.org/licenses/by/4.0/), which permits use, sharing, adaptation, distribution and reproduction in any medium or format, as long as you give appropriate credit to the original author(s) and the source, provide a link to the Creative Commons license and indicate if changes were made.

The images or other third party material in this chapter are included in the chapter's Creative Commons license, unless indicated otherwise in a credit line to the material. If material is not included in the chapter's Creative Commons license and your intended use is not permitted by statutory regulation or exceeds the permitted use, you will need to obtain permission directly from the copyright holder. 